\title{
Kebersyukuran dan Kepuasan Hidup pada Orangtua dengan Anak Berkebutuhan Khusus
}

\author{
Adhyatman Prabowo \\ Program Studi Psikologi, Fakultas Psikologi Universitas Muhammadiyah Malang, Malang
}

\begin{abstract}
Every parents hope to have children born perfect, both physically and mentality. However, some children are born with disability physically or mentality that is called child with special need. The purpose this research is understanding and explaining relationship between gratitude and life satisfactions parents who have child with special need. The methodology used correlational quantitative methods. The subject of this research is parents who have child with special need and stay in Malang. The method of sample is used cluster sampling method and collected data through Satisfaction with Life Scale (SWLS) is constructed by Diener, Emmons, Larsen and Griffin (1985) that was consisted of five items with Alpha coefficient 0.710 and The Gratitude Questionnaires Six Item Form (GQ-6) in the form of Likert Scale is constructed by McCullough et.al (2002) that was consisted of six items with Alpha Coefficient 0.765 . While data analysis used the data analysis correlation the Pearson's Product Moment correlation. The result of this research showed a significant correlation between gratitude and life satisfaction $(p=0,000 ; p<0,001)$ with score of correlation's coefficient 0.470 . Thus, this means that gratitude is positively correlated with life satisfaction. This finding will be discussed later in this paper.
\end{abstract}

Keywords: gratitude, life satisfaction, parents with special needs children

\begin{abstract}
Abstrak. Setiap orang tua pasti berharap memiliki anak yang terlahir sempurna secara jasmani maupun rohani. Namun, ada kalanya anak yang dilahirkan memiliki keterbatasan baik secara fisik maupun psikis yang telah dialami sejak awal masa perkembangan. Kasus tersebut biasanya disebut sebagai anak berkebutuhan khusus. Tujuan dari penelitian ini adalah mengetahui hubungan antara kebersyukuran dan kepuasan hidup pada orangtua dengan anak berkebutuhan khusus. Metode penelitian ini menggunakan metode kuantitatif korelasional. Subjek penelitian yaitu orangtua dengan anak berkebutuhan khusus yang berjumlah 53 orang dan bertempat tinggal di Malang. Adapun metode pengambilan sampel yang digunakan adalah metode cluster sampling. Teknik pengumpulan data dalam penelitian ini menggunakan skala Satisfaction With Life Scale (SWLS) yang disusun Diener, Emmons, Larsen dan Griffin (1985) sebanyak lima butir pernyataan dengan koefisien Alpha sebesar 0.710 dan The Gratitude Questionnaires Six Item Form (GQ-6) berupa skala Likert yang disusun oleh McCullough, Emmons, dan Tsang (2002) sejumlah enam butir pernyataan dengan koefisien Alpha sebesar 0.765, sedangkan analisis data menggunakan metode korelasi Product Moment dari Pearson. Hasil penelitian menunjukkan bahwa terdapat hubungan antara kebersyukuran dengan kepuasan hidup ( $\mathrm{p}=0.000 ; \mathrm{p}<0.001)$ dengan nilai koefisien korelasi sebesar 0.470 . Hal ini berarti semakin tinggi kebersyukuran seseorang, maka semakin tinggi pula kepuasan hidup pada orangtua dengan anak berkebutuhan khusus, dan begitu pula sebaliknya.
\end{abstract}

Kata kunci: kebersyukuran, kepuasan hidup, orang tua anak berkebutuhan khusus

Korespondensi: Adhyatman Prabowo. Email: adhyatmanprabowo@umm.ac.id 
Setiap orangtua pasti berharap memiliki anak yang terlahir sempurna secara jasmani maupun rohani. Namun, ada kalanya anak yang dilahirkan memiliki keterbatasan baik secara fisik maupun psikis yang telah dialami sejak awal masa perkembangan dan umumnya disebut sebagai anak berkebutuhan khusus. Anak berkebutuhan khusus yaitu anak yang mengalami kelainan atau gangguan fisik (fisik, mental-intelektual, sosial dan emosional) dalam proses pertumbuhan dan perkembangannya dibandingkan dengan anakanak lain seusianya, serta memerlukan pelayanan pendidikan khusus (Direktorat Pembinaan SLB, 2005).

Kepuasan hidup merupakan penilaian kognitif seseorang terhadap kehidupan yang ditandai kemampuan individu untuk memandang hidupnya dengan baik dan memuaskan, dengan cara membandingkan kondisi yang dialami saat ini dengan standar kepuasan hidup yang dimiliki. Individu yang memiliki kepuasan hidup yang tinggi akan mendapatkan kebahagiaan dan kesejahteraan psikologis (Demirbatir, Helvaci, Yilmaz, Gul, 2013; Garcia \& Archer, 2012). Menurut Diener, Emmons, Larssen dan Griffin (1985), kepuasan hidup merupakan proses penilaian kognitif pada diri seseorang yang bergantung pada perbandingan keadaan dirinya dengan standar yang sesuai baginya, Sedangkan Sousa dan Lyubomirsky (2001) mendefinisikan kepuasan hidup sebagai sebuah penilaian subjektif dari kualitas hidup seseorang. Pengertian tersebut senada dengan yang diungkapkan oleh Shin dan Johnson (Diener, Emmons, Larsen, \& Griffin, 1985) bahwa kepuasan hidup merujuk pada penilaian global seseorang terhadap kualitas hidupnya menurut kriteria yang dipilihnya. Kemudian Huebner, Drane dan Valois (2000) mengungkapkan bahwa kepuasan hidup merupakan evaluasi kognitif seseorang terhadap hidupnya secara global. Selanjutnya Diener, Emmons, Larsen dan Griffin (1985) mengungkapkan lima komponen dari kepuasan hidup, yaitu keinginan untuk mengubah kehidupan, kepuasan terhadap kehidupan saat ini, kepuasan hidup di masa lalu, kepuasan terhadap kehidupan di masa mendatang, dan penilaian terhadap kehidupan. Di sisi lain, salah satu kepuasan hidup merupakan harapan dari setiap manusia. Kepuasan hidup digambarkan sebagai bentuk penilaian individu secara menyeluruh dalam menilai puas atau tidaknya kehidupan yang dialaminya (Hurlock, 2009). Berdasarkan paparan di atas, maka kepuasan hidup dapat dimaknai sebagai penilaian secara kognitif atas kehidupan yang telah dijalani individu secara keseluruhan.

Kepuasan hidup bagi orangtua dengan anak berkebutuhan khusus merupakan hal yang penting. Hasil penelitian dari Smith dan Grzywacz (2014) menunjukkan bahwa ada perbedaan tingkat kesejahteraan dan kesehatan mental pada orangtua dengan anak berkebutuhan khusus dan orangtua yang memiliki anak dengan perkembangan normal. Hasilnya adalah orangtua dengan anak 
berkebutuhan khusus melaporkan lebih tinggi tingkat depresi dan kesehatan mental yang lebih rendah. Hasil riset tersebut didukung pula oleh riset dari Shenaar-Golan (2016). Riset tersebut menunjukkan bahwa kepuasan hidup (sebagai bagian dari kesejahteraan subjektif) orangtua dengan disabilitas perkembangan lebih rendah dibandingkan rata-rata masyarakat pada umumnya. Berdasarkan hasil dari kedua penelitian tersebut maka tampak bahwa kepuasan hidup pada orangtua dengan anak berkebutuhan khusus memiliki permasalahan yang lebih tinggi.

Ada beragam faktor yang memengaruhi kepuasan hidup. Salah satu faktor yang berpengaruh adalah kebersyukuran (Sansone \& Sansone, 2010). Kebersyukuran didefinisikan dalam berbagai literatur sebagai emosi, nilai moral, sikap, sifat kepribadian dan gaya koping. Kebersyukuran (gratitude) berasal dari bahasa Latin gratia yang berarti penuh rasa syukur (Lopez \& Snyder, 2003). Menurut Emmons (2007), segala kata yang berasal dari kata gratia selalu berhubungan dengan kebaikan, kemurahan hati, dan keindahan memberi maupun menerima. Seligman dan Peterson (Putri, 2012) mendefinisikan kebersyukuran sebagai suatu perasaan terima kasih dan menyenangkan atas respon penerimaan hadiah yang memberikan manfaat dari seseorang atau suatu kejadian yang memberikan rasa damai. Lebih lanjut, mereka menjelaskan bahwa kebersyukuran merupakan salah satu kekuatan positif yang memberikan keuntungan besar bagi diri individu.

Kebersyukuran memiliki kedudukan utama dalam berbagai pandangan filosofis maupun religius. Agama-agama seperti Islam, Kristen, Hindu dan Buddha telah mengakui pentingnya kebersyukuran (Emmons \& Crumpler, 2000). Berdasarkan pandangan tersebut, maka kebersyukuran disebut sebagai nilai terbesar dalam diri individu dan menjadi induk dari nilai-nilai kebaikan yang lain. Kebersyukuran merupakan suatu bentuk emosi positif dalam mengekspresikan kebahagiaan dan rasa terima kasih terhadap segala kebaikan yang diterima (Seligman, 2002). Individu bersyukur karena menyadari bahwa dirinya banyak menerima kebaikan, penghargaan dan pemberian baik dari Tuhan, orang lain dan lingkungan sekitarnya sehingga terdorong untuk membalas, menghargai dan berterima kasih atas segala sesuatu yang diterimanya dalam bentuk perasaan, perkataan dan perbuatan.

Selain itu, secara konseptual, kebersyukuran terbagi dalam dua tingkat, yaitu keadaan (state) dan sifat (trait). Kebersyukuran sebagai sebuah keadaan, berarti perasaan subjektif berupa kekaguman, berterima kasih dan menghargai segala sesuatu yang diterima, sedangkan sebagai sifat, kebersyukuran merupakan kecenderungan seseorang untuk merasa bersyukur dalam hidupnya. Meskipun demikian, kecenderungan untuk merasakan kebersyukuran itu tidak selalu muncul, namun seseorang yang memiliki kecenderungan ini 
akan lebih sering berterima kasih dalam situasisituasi tertentu. McCullough, Emmons, dan Tsang ( $\left(\begin{array}{llll}2 & 0 & 0 & 2\end{array}\right)$ membedakan sifat kebersyukuran dalam empat aspek, yaitu: (1) Intensitas, artinya sangat bersyukur ketika terjadi hal-hal positif, (2) Frekuensi artinya individu sering mengungkapkan rasa syukur setiap hari, (3) Rentang / Keluasan artinya individu merasa bersyukur dalam berbagai keadaan hidup (seperti bersyukur atas pekerjaan, kesehatan dan keluarga yang dimiliki), (4) Densitas artinya individu sering merasakan perasaan berterima kasih terhadap lebih banyak orang.

Keterkaitan antara kedua variabel tersebut dapat dilihat dari beberapa hal. Pertama, adalah kebersyukuran merupakan strategi psikologis yang membantu individu untuk memaknai pengalaman sehari-hari. Pada saat yang sama, pemaknaan tersebut akan berfokus pada berbagai hal baik atau kelebihan yang didapatkan berdasarkan peristiwa tersebut (Salvador-Ferrer, 2017). Kemudian, persepsi yang positif atas peristiwa tersebut cenderung akan meningkatkan emosi positif (Sansone \& Sansone, 2010). Emosi positif yang dirasakan secara intens akan mendukung tercapainya kepuasan hidup. Di dalam konteks orangtua dengan anak berkebutuhan khusus, kebersyukuran akan membantu dalam melihat sisi positif dari tumbuh kembang anaknya. Hal tersebut cenderung akan meningkatkan perasaan positif dalam dirinya. Oleh sebab itu, diduga emosi positif yang dirasakan sebagai bagian dari kebersyukuran akan berkaitan dengan munculnya kepuasan hidup.

Berdasarkan paparan di atas, maka peneliti ingin mengetahui lebih lanjut mengenai hubungan kebersyukuran dan kepuasan hidup orangtua yang memiliki anak berkebutuhan khusus. Hal ini menjadi penting sebab akan berdampak pada keberhasilan pendidikan dan pengasuhan anak yang berkebutuhan khusus di masa mendatang. Adapun hipotesis penelitian ini adalah terdapat hubungan antara kebersyukuran dan kepuasan hidup pada orangtua dengan anak berkebutuhan khusus.

\section{Metode}

\section{Rancangan penelitian}

Penelitian ini menggunakan jenis penelitian kuantitatif. Penelitian kuantitatif merupakan suatu pendekatan penelitian yang banyak menggunakan angka mulai dari pengumpulan data, penafsiran data hingga penampilan hasilnya (Sugiyono, 2012). Adapun metode yang digunakan dalam penelitian ini adalah studi korelasi yaitu mengetahui hubungan variasi dalam sebuah variabel dengan variasi dalam variabel lain.

\section{Subjek penelitian}

Karakteristik subjek penelitian ini adalah orangtua yang memiliki anak berkebutuhan khusus di Malang. Jenis kebutuhan khusus pada penelitian ini bervariasi, meliputi gangguan autisme, 
retardasi mental, maupun ketunaan dari sisi penginderaan (tunanetra, tunarungu, dan tunawicara). Teknik pengambilan sampel yang digunakan adalah metode cluster sampling. Cluster sampling merupakan pengambilan sampel yang didasarkan pada area atau cluster. Cluster yang dimaksud dalam penelitian ini adalah sekolah yang terdapat anak berkebutuhan khusus.

\section{Instrumen pengumpulan data}

Variabel tergantung dalam penelitian ini adalah kepuasan hidup yaitu suatu kondisi individu merasakan kepuasan terhadap kualitas hidup yang dimilikinya. Dalam penelitian ini kepuasan hidup diukur dengan Satisfaction With Life Scale (SWLS) berbentuk skala Likert yang disusun berdasarkan komponen-komponen kepuasan hidup yang diungkapkan oleh Diener, Emmons, Larsen dan Griffin (1985). Instrumen ini diadaptasi dari instrumen aslinya yang berbahasa Inggris. Instrumen tersebut terdiri dari lima butir pernyataan, dan berdasarkan hasil uji coba menunjukkan bahwa tidak ada butir yang gugur.

Variabel kebersyukuran akan diukur dengan The Gratitude Questionnaires Six Item Form (GQ-6) berupa skala Likert yang disusun oleh McCullough, Emmons, dan Tsang (2002).

Instrumen ini terdiri dari enam butir pernyataan dan juga tidak ada butir yang gugur. Validitas instrumen penelitian menunjukkan akurasi atau kecermatan hasil ukur sebuah atribut atau variabel (Azwar, 2013). Dalam analisa validitas instrumen ini, r-tabel memiliki nilai sebesar 0.195 dengan jumlah subjek 100 dan signifikansi 5\% untuk uji dua sisi (Coolican, 2004 ). Indeks validitas item dilihat berdasarkan nilai korelasi skor butir dengan skor total (r-hitung). Jika nilai r-hitung lebih besar dari r-tabel $=0.195$ maka butir tersebut valid dan dapat digunakan dalam penelitian. Berdasarkan hasil uji coba, tidak ada butir yang gugur pada kedua instrumen tersebut. Berikut ini adalah rincian indeks validitas dari masingmasing instrumen penelitian:

Tabel 1. Indeks Diskriminan Instrumen Penelitian

\begin{tabular}{lccc}
\hline \multicolumn{1}{c}{ Instrumen } & $\begin{array}{c}\text { Jumlah Butir Saat } \\
\text { Uji Coba }\end{array}$ & $\begin{array}{c}\text { Jumlah Butir } \\
\text { Setelah Uji Coba }\end{array}$ & $\begin{array}{c}\text { Indeks } \\
\text { Diskriminan }\end{array}$ \\
\hline $\begin{array}{l}\text { The Satisfaction With Life Scale } \\
\text { (SWLS) }\end{array}$ & 5 & 5 & $0,258-0,635$ \\
$\begin{array}{l}\text { The Gratitude Questionnaires Six } \\
\text { Item Form (GQ-6) }\end{array}$ & 6 & 6 & $0,349-0,695$ \\
\hline
\end{tabular}


Selain indeks validitas, koefisien reliabilitas instrumen menjadi sesuatu yang sangat penting untuk diuji karena reliabilitas instrumen menunjukkan sejauh mana hasil pengukuran dengan instrumen tersebut dapat dipercaya (Azwar, 2013). Dalam penelitian ini, koefisien reliabilitas yang ditunjukkan oleh menganalisis kekuatan hubungan antara kedua variabel.

\section{Hasil}

Penelitian ini melibatkan 53 orang subjek penelitian dengan memiliki

Tabel 2. Koefisien Reliabilitas Instrumen

\begin{tabular}{lc}
\hline \multicolumn{1}{c}{ Instrumen Penelitian } & Cronbach's Alpha \\
\hline The Satisfaction With Life Scale (SWLS) & 0,710 \\
The Gratitude Questionnaires Six Item Form & 0,765 \\
(GQ-6) & \\
\hline
\end{tabular}

koefisien Cronbach's Alpha. Menurut Gaur dan Gaur (2009), nilai Cronbach's Alpha di atas 0,7 dapat dikatakan sebagai reliabilitas skala yang cukup bagus untuk digunakan dalam penelitian. Berikut ini adalah detail koefisien Cronbach's Alpha dari masing-masing instrumen penelitian.

Berdasarkan Tabel 2, dapat disimpulkan bahwa instrumen yang dipakai dalam penelitian ini reliabel karena memiliki koefisien reliabilitas di atas 0.7 dan dalam Tabel 1 diketahui bahwa instrumen tersebut memiliki indeks validitas yang memadai sehingga instrumen tersebut layak untuk dipakai dalam penelitian.

\section{Analisis data penelitian}

Penelitian ini menggunakan metode korelasi Product Moment dari Pearson untuk karakteristik yang dijelaskan pada tabel 3.

Berdasarkan tabel 3, dapat diketahui karakteristik subjek penelitian berdasarkan usia yang paling dominan adalah usia $31-40$ tahun yaitu 24 orang (45\%). Jenjang pendidikan paling banyak terdapat pada jenjang pendidikan Sekolah Menengah Atas (SMA) yakni 31 orang (58\%). Selain itu, jenis klasifikasi gangguan anak yang paling banyak terdapat pada gangguan autisme yakni 33 orang (62\%).

Berdasarkan tabel 4 diketahui hasil uji hipotesis menggunakan uji korelasi Pearson menunjukkan hasil $\mathrm{p}=0.000(\mathrm{p}<0.01)$ dengan nilai koefisiensi 0.470 . Hal ini berarti ada hubungan antara kebersyukuran dan kepuasan hidup pada orang tua dengan anak berkebutuhan khusus. 
Tabel 3. Deskripsi Subjek Penelitian

\begin{tabular}{cc}
\hline Kategori & Jumlah (Persentase) \\
\hline Usia & $5(9 \%)$ \\
$31-40$ & $24(45 \%)$ \\
$41-50$ & $20(38 \%)$ \\
$>50$ & $4(8 \%)$ \\
Pendidikan & \\
S2 & $1(2 \%)$ \\
S1 & $8(15 \%)$ \\
Diploma & $4(8 \%)$ \\
SMA & $31(58 \%)$ \\
SMP & $2(4 \%)$ \\
SD & $7(13 \%)$ \\
Klasifikasi gangguan anak & \\
Autisme & $33(62 \%)$ \\
Down syndrome & $5(9 \%)$ \\
Tunagrahita & $10(19 \%)$ \\
Tunanetra & $1(2 \%)$ \\
Tunarungu & $2(4 \%)$ \\
Tunawicara & $2(4 \%)$ \\
\hline
\end{tabular}

Tabel 4. Hasil Analisa Data Penelitian

\begin{tabular}{ccccccc}
\hline Variabel & $\mathrm{N}$ & rerata & SD & $\mathrm{r}$ & $\mathrm{p}$ & Keterangan \\
\hline Kebersyukuran & 53 & 27,60 & 4,016 & 0,470 & 0,000 & Signifikan \\
Kepuasan Hidup & 53 & 19,83 & 5,124 & & & \\
\hline
\end{tabular}

\section{Pembahasan}

Hasil penelitian menunjukkan bahwa terdapat hubungan positif antara kebersyukuran dan kepuasan hidup. Hal ini berarti semakin tinggi kebersyukuran pada orangtua anak berkebutuhan khusus, maka semakin tinggi pula tingkat kepuasan hidupnya, dan begitu pula sebaliknya. Hasil penelitian ini senada dengan berbagai riset terkait kedua variabel tersebut. Kebersyukuran ditemukan berkorelasi positif dengan tingkat kepuasan hidup walaupun dari kondisi subjek yang berbeda (Chen, Wu, \& Chang, 2017; SalvadorFerrer, 2017). Berdasarkan hasil dari kedua penelitian ini, maka kebersyukuran memiliki korelasi positif dengan kepuasan hidup di berbagai negara dan dengan subjek yang bervariasi. 
Hal tersebut dikuatkan oleh dinamika bahwa kebersyukuran juga memiliki korelasi positif dengan afek positif yang dapat berdampak pada pengembangan diri dan perubahan positif (Christina, Armenta, Fritz, \& Lyubomirsky, 2016). Hal ini juga didukung oleh hasil penelitian yang dilakukan McCullough, Emmons, dan Tsang (2002) yang menemukan bahwa kebersyukuran berkorelasi positif terhadap kesejahteraan dan afek positif seperti kepuasan hidup, kebahagiaan subjektif, vitalitas, optimisme, dan harapan, sekaligus berkorelasi negatif pada afek negatif seperti kecemasan, depresi, dan sikap negatif lainnya.

Peran afek positif juga berpengaruh pada orangtua yang memiliki anak berkebutuhan khusus. Hal tersebut diungkap pula oleh Kandel dan Merrick (2007) yang menunjukkan bahwa respon yang diberikan orangtua, seperti penerimaan orang tua, manajemen, dan strategi koping berpengaruh pada perkembangan anak berkebutuhan khusus. Apabila anak berkebutuhan khusus didukung oleh afek positif yang dimiliki orangtuanya, maka mereka akan memiliki perkembangan yang positif. Sebaliknya, jika respon orangtua yang tampak lebih banyak afek negatif, maka akan berdampak negatif pada tumbuh kembang anak berkebutuhan khusus.

Orangtua dengan anak berkebutuhan khusus memiliki reaksi individu yang berbedabeda, mulai dari terkejut, penolakan, sedih dan marah, menerima dan reorganisasi. Menurut
Cohen dan Volkmar (1997) banyak orangtua yang mengalami stres, kecemasan bahkan berujung pada krisis kepercayaan diri. Oleh karena itu, pentingnya orangtua dengan anak berkebutuhan untuk memiliki afek positif sehingga dapat meningkatkan kepuasan hidup pada orangtua dengan anak berkebutuhan khusus.

Orangtua yang memiliki tingkat kebersyukuran tinggi maka akan lebih mudah bersyukur ketika terjadi hal-hal positif, sering mengungkapkan rasa syukur setiap hari, merasa bersyukur dalam berbagai keadaan hidup (seperti bersyukur atas pekerjaan, kesehatan dan keluarga yang dimiliki) dan individu sering berterimakasih terhadap lebih banyak orang. Dengan demikian, hal tersebut akan menjadikan individu menjadi pribadi yang mampu mengubah kehidupan, puas terhadap kehidupan saat ini, masa lalu dan yang akan datang serta mampu menilai secara positif tentang kehidupan.

Penelitian ini masih memiliki beberapa kelemahan, antara lain usia anak belum dideskripsikan dengan jelas. Hal ini memungkinkan bahwa usia anak juga berperan dalam tingkat kesulitan orangtua dalam pengasuhan sehari-hari. Selain itu, jumlah subjek di masing-masing kelompok kebutuhan khusus pada anak belum proporsional. Hal ini akan menarik jika dikaji di penelitian selanjutnya untuk membandingkan kondisi di masing-masing jenis kebutuhan khusus.. 


\section{Simpulan}

Hasil penelitian menunjukkan bahwa terdapat hubungan yang positif dan signifikan antara kebersyukuran dengan kepuasan hidup. Semakin tinggi tingkat kebersyukuran, maka semakin tinggi kepuasan hidup pada orang tua dengan anak berkebutuhan khusus. Sebaliknya, semakin rendah kebersyukuran maka semakin rendah pula kepuasan hidup pada orang tua dengan anak berkebutuhan khusus.

\section{Saran}

Saran untuk peneliti selanjutnya adalah melakukan penelitian pada karakteristik subjek yang lebih bervariasi dan menambahkan variabel eksternal lainnya.

\section{Daftar Pustaka}

Azwar, S. (2013). Reliabilitas dan Validitas. Yogyakarta: Pustaka Pelajar.

Chen, L. H., Wu, C. H., \& Chang J. H. (2017). Gratitude and athletes' life satisfaction: The moderating role of mindfulness. Journal of Happiness Studies, 18(4), 1147-1159. http//dx:doi.10. 1007/s10902-016-9764-7.

Christina, N., Armenta, C. N., Fritz, M. M., \& Lyubomirsky. S. (2016). Functions of positive emotions: Gratitude as a motivator of self-improvement and positive. Riverside, USA: Emotion Review Department of Psychology,
University of California,

Coolican, H. (2004). Research Methods and Statistics in Psychology. London: British Library Catalogue in Publication Data.

Cohen, D. J., \& Volkmar, F.R. (1997). Handbook of Autism and Pervasive Development Disorder (2end) . New York : John Wiley \&Sons, Inc.

Demirbatir, E., Helvaci, A., Yilmaz, N., \& Gul, G. (2013). The psychological well-being, happiness, and life satisfaction of music students. Psychology, 4(11A), 16-24.

Diener, E., Emmons, R. A., Larsen, R. J., \& Griffin, S. (1985). The satisfaction with life scale. Journal of Personality Assessment, 49, 71-75.

Direktorat Pembinaan SLB. (2005). Pedoman Penyelenggaraan Pendidikan Terpadu/Inklusif, Penilaian Hasil Belajar Siswa pada Kelas Inklusif / Terpadu. Jakarta: Direktorat PSLB, Ditjen Manajemen Dikdsmen, Depdiknas.

Emmons, R. A. (2007). Thanks! How The New Science of Gratitude Can Make You Happier. New York: Houghton Mifflin Company.

Emmons, R. A., \& Crumpler, C. A. (2000). Gratitude as a human strength: Appraising the evidence. Journal of Social and Clinical Psychology, 19(1), 566 9 http://dx.doi.10.1521/jscp.2000.19.1. 
56.

Garcia, D., \& Archer, T. (2012). Adolescent life satisfaction and well-being. Journal of Alternative Medicine Research, 4(3), 271-279.

Gaur, A. S., \& Gaur, S. S. (2009). Statistical Methods For Practice and Research : A Guide to Data Analysis Using SPSS. New Delhi: Response Books, SAGE Publications Inc.

Huebner, E.S., Drane, J.W., \& Valois, R.F. (2000). Levels and demographic correlates of adolescent life satisfaction report. School Psychology International, 21, 281 $-292$.

Hurlock, E. B. (2009). Psikologi Perkembangan: Suatu Perkembangan Sepanjang Rentang Kehidupan. Jakarta: Erlangga.

Kandel. I., \& Merrick. J (2007) The child with a disability: parental acceptance, management and coping. Journal The Scientific World , 7 (2007), 1799-1809.

Lopez, S.J., \& Snyder, C.R. (2003). Positive Psychological Assessment: A Handbook of Models and Measures. Washington. DC :American Psychological Association.

McCullough, M. E., Emmons, R. A., \& Tsang, J. (2002). The grateful disposition: A conceptual and empirical topography. Journal of Personality and Social Psychology, 82(1), 112-127. http://dx.doi.10.1037/00223514.82.1.112.
Putri, F. O. (2012). Hubungan antara gratitude dan psychological well-being pada mahasiswa. Skripsi Fakultas Psikologi Universitas Indonesia: Tidak Diterbitkan.

Salvador-Ferrer, C. (2017). The relationship between Gratitude and Life satisfaction in a sample of Spanish university students: The moderation role of gender. Anales de Psicología, 33(1), 114$1 \quad 1 \quad 9$. http://dx.doi.10.6018/analesps.32.3.2 26671.

Sansone, R. A., \& Sansone, L. A. (2010). Gratitude and well-being: The benefits of appreciation. Psychiatry, 7(11), 18-22.

Seligman, M. E. P. (2002). Authentic happiness: Using The New Positive Psychology to Realize Your Potential for Lasting Fulfillment. New York: Free Press.

Shenaar-Golan, V. (2016). The Subjective wellbeing of parents of children with developmental disabilities: The role of hope as predictor and fosterer of wellbeing. Journal of Social Work in Disability and Rehabilitation, 15(2), 7795.http://dx.doi.10.1080/1536710x.1 016.1162119 .

Smith, A. M., \& Grzycwacz, J. G. (2014). Health and well-being in midlife parents of children with special health needs. Family System Health, 32(3), 303-312.

Sousa, L., \& Lyubomirsky, S. (2001). Life 
Satisfaction. In J.Worell (Ed.), Encyclopedia of Woman and Gender: Sex Similarities and Differences and The Impact of Society on Gender, 22, 667 - 676. San Diego: Academic Press.

Sugiyono. (2012). Metode Penelitian Kuantitatif Kualitatifdan R\&B. Bandung: Alfabeta. 